\section{Kematangan emosi dalam perilaku ujaran kebencian pada kebijakan politik}

\author{
Muhammad Faisal Abdul Afif ${ }^{1}$, Yuni Nurhamida ${ }^{1}$, dan Fath Mashuri ${ }^{1}$
}

\begin{abstract}
The widespread use of social media by Indonesians has both positive and negative impacts. In addition, to making it easier for us to find information and reading sources, the use of social media also leaves negative impacts such as hate speech behavior that occurs on social media. One of the things that are thought to be correlated with hate speech behavior is emotional maturity. The purpose of this study was to determine the relationship between emotional maturity and hate speech behavior on social media towards political issues in Indonesia. The method used in this research is correlational quantitative, and using purposive sampling to select the subjects. Subjects of research were 205 person. In measuring the emotional maturity of this study using a Likert scale and hate speech behavior using a vignette scale. Data were analyzed using by the person product moment analysis technique. The results were that there was a negative relationship between the two variables with a significance value of $<0.001$ and a correlation coefficient value of -0.313 , which means that the higher the emotional maturity of a person, the lower the level of hate speech behavior will be, and vice versa.
\end{abstract}

\title{
Keywords
}

Social media, emotional maturity, hate speech, political issues

\section{Pendahuluan}

Media sosial merupakan salah satu dari perkembangan teknologi yang berbasis pada penggunaan internet. Penggunaan media sosial saat ini sudah menjadi bagian dari kehidupan manusia pada zaman milenial ini. Sosial media juga memberikan banyak fitur yang memudahkan kepada penggunanya. Menurut hasil riset dari Wearesosial Hootsuite pada Januari 2019 (Wearesosial, 2019), pengguna media sosial di Indonesia mencapai 150 juta atau sebesar $56 \%$ dari total penduduk.Usia pengguna media sosial paling banyak adalah pada rentang 18 sampai 34 tahun (Kompas.com, 2018).

Banyak fitur yang ditawarkan dalam media sosial tergantung pada platform apa yang digunakan. Namun pada dasarnya, semua media sosial memiliki kegunaan yang sama, yaitu untuk mendapatkan dan memberikan informasi tentang semua hal. Semakin dimudahkannya kita dalam mengakses media sosial, maka tidak dapat dipungkiri banyak pula dampak negatif dari perkembangannya. Salah satu dampak negatif yang ditimbulkan adalah ujaran kebencian atau sering disebut dengan hate speech. Di Indonesia, ujaran kebencian termasuk dalam kejahatan jaringan atau sering kita sebut dengan cyber crime.

Purnamasari (2018) memaparkan bahwa pada sepanjang tahun 2018, terdapat 324 kasus yang terkait dengan perilaku ujaran kebencian. Jika dianalogikan, pada tahun 2018 hampir setiap hari ada kasus ujaran kebencian yang muncul. Sedangkan pada tahun 2019, dalam skala periode bulan Januari hingga bulan Juni, sudah terdapat 101 kasus tentang ujaran kebencian (Al Ayyubi, 2018). Kasus tentang ujaran kebencian yang ada di Indonesia biasanya dipicu oleh isu politik dan berkaitan dengan salah satu golongan. Ujaran tersebut banyak mengandung kalimat sarkas, berita bohong, atau bahkan menyudutkan agama tertentu.

Sukmana (2018) memaparkan Amnesty International mengeluarkan laporan tahunannya mengenai situasi HAM di dunia, dengan hasil bahwa tahun 2017 merupakan tahun yang penuh dengan isu kebencian. Sedangkan di Indonesia sendiri tidak jauh berbeda dengan hasil laporan yang diungkapkan sebelumnya. Salah satu pembeda di Indonesia adalah ujaran kebencian yang terjadi memiliki keterkaitan yang erat dengan isu politik. Hal ini terjadi semenjak pemilihan Kepala Daerah DKI Jakarta. Kasus ujaran kebencian juga marak terjadi sebelum dan sesudah pemilihan presiden beserta staf legislatifnya (Sukmana, 2018).

Dilihat dari beberapa kasus di atas, dapat disimpulkan bahwa tingginya perilaku menyimpang dan penyalahgunaan media sosial yaitu ujaran kebencian sangat tinggi. Komisi Nasional Hak Asasi Manusia (2016) menjelaskan ujaran kebencian adalah tindakan komunikasi yang dilakukan oleh seseorang atau sekelompok orang dengan bentuk komunikasi berupa provokasi, hasutan, ataupun hinaan kepada orang atau kelompok lain dalam berbagai aspek seperti ras, warna kulit, gender, cacat, orientasi seksual, kewarganegaraan, agama, dan hal-hal lain.

\footnotetext{
${ }^{1}$ Universitas Muhammadiyah Malang

\section{Korespondensi:}

Muhammad Faisal Abdul Afif, Fakultas Psikologi, Universitas Muhammadiyah Malang

Email: Afiffaisal45@gmail.com
} 
Kebencian adalah emosi negatif yang diungkapkan seseorang untuk mengutarakan perasaannya terhadap suatu hal yang ia dapatkan. Kebencian sendiri menurut White (1996) adalah suatu keinginan untuk mencelakakan, mempermalukan, atau bahkan membunuh objek yang dibenci. Halperin (2008) mengungkapkan pendapatnya bahwa kebencian adalah sebuah perasaan negatif yang kuat yang ditujukan kepada kelompok luar (out group) sehingga kelompok pembenci (ingroup hate) memiliki keinginan untuk merusak dan menghancurkan outgroup. Hal ini juga dapat dilihat dari hasil penelitian yang dilakukan oleh Halperin (2008) pada Yahudi yang berada di Israel, yang menunjukkan bahwa kebencian yang didasari kelompok memiliki ciri tujuan yang motivasional spesifik untuk merusak, menghilangkan, dan menghapus outgroup. Kebanyakan tujuan tersebut disertai keinginan melakukan tindakan tertentu untuk tidak memaafkan dan menyerang (Fisher et al., 2018). Penelitian Halperin (2008) juga menyebutkan bahwa 83,3\% peserta mengungkapkan bahwa mereka ingin sesuatu yang buruk terjadi pada kelompok yang dibenci. Sebanyak 16,6\% peserta juga melakukan tindakan kekerasan pada kelompok yang dibenci.

Fungsi sosial dalam emosi ini tidak hanya untuk menyakiti, namun pada akhirnya akan menghilangkan atau menghancurkan objek yang dibenci, baik menyerang secara mental dengan cara menghina atau membalas dendam, secara sosial dengan cara mengabaikan atau mengisolasi, secara fisik seperti dengan menyiksa atau membunuh, atau menyertakan tujuan untuk membiarkan objek yang dibenci menderita. Terdapat beberapa bentuk dalam mengungkapkan kebencian, di antaranya adalah diawali dengan kekerasan verbal, kemudian meningkat menjadi sebuah intimidasi dan kekerasan fisik. Kejahatan kebencian dapat menimbulkan trauma psikologis bagi korban dan jika terjadi dalam skala luas, dapat menimbulkan kekhawatiran, ketakutan, kecurigaan, serta permusuhan di antara subjek pembenci dan objek yang dibenci (Azra, 2018). Ujaran kebencian dapat menyerang secara mental jika dilakukan dengan cara menghina atau memfitnah, di mana hal ini bertujuan untuk mencelakakan atau mempermalukan objek yang dibenci. Dampak dari perilaku ini sendiri adalah memicu terjadinya kekerasan dan menimbulkan prasangka.

Kebencian juga merupakan perasaan yang sangat ekstrim dan mendalam. Kebencian sering dikaitkan dengan permusuhan kepada objek yang dibenci. Rasa permusuhan ini akan menimbulkan dorongan pada subjek yang membenci untuk melakukan perilaku ekstrem seperti tindakan kekerasan baik secara fisik maupun mental. Ada tiga pendekatan teoritis yang dapat menjelaskan tentang penyebaran kebencian, yakni berkaitan dengan status ekonomi, identitas dari sebuah budaya, dan hal yang berfokus kepada atribut umum masyarakat, politik misalnya (Bavel et al., 2014). Politik pada era sekarang adalah hal yang sensitif, terlebih setelah pemilihan presiden dan wakil rakyat lainnya. Banyak statement atau keputusan yang diberikan oleh para pelaku politik dan jajarannya yang tidak jarang mengundang penyebab polemik dan kontroversial. Hal ini dapat menimbulkan sebuah kritikan, hujatan, hinaan, dan ujaran kebencian, baik secara langsung maupun tidak langsung melalui berbagai media yang ada.
Penelitian yang dilakukan oleh Sinaga (2019) mengatakan bahwa postingan ujaran kebencian dalam media sosial yang paling sering terlihat adalah mengenai politik, kebijakan pemerintah yang kemudian disusul oleh SARA, atau kontroversi tokoh publik. Ada beberapa faktor ujaran kebencian, di antaranya adalah salah paham, terbawa emosi, kebencian pribadi, iseng, dan hanya sekadar untuk menasehati. Menurut penelitian lain tentang penyebab ujaran kebencian yang dilakukan oleh Febriani (2018), faktor penyebab kebencian dibagi menjadi dua, yaitu internal dan lingkungan. Faktor internal individu contohnya seperti keadaan psikologis dan kematangan emosional. Kemudian untuk faktor lingkungan, terdiri dari kurangnya kontrol sosial, kepentingan kelompok atau masyarakat, dan ketidaktahuan masyarakat. Namun dari hasil penelitian yang dilakukan, faktor yang paling sering menjadi penyebab adalah faktor psikologis dan keadaan emosional individu yang melakukannya. Selain itu, faktor sarana umum dan kepentingan politik juga berpengaruh besar dalam perilaku ujaran kebencian.

Penelitian yang dilakukan oleh Trajkova \& Neshkova (2018) menyebutkan bahwa tindakan ujaran kebencian pada media sosial dilakukan oleh setiap kalangan dalam masyarakat, baik politisi, aktivis politik, dan masyarakat. Unggahan yang mereka tuliskan berisi tentang pidato kebencian. Di sini dapat disimpulkan bahwa beberapa faktor yang memengaruhi perilaku ujaran kebencian adalah keadaan emosional individu. Bagaimana keadaan emosi individu ketika menghadapi isu yang beredar dan menghadapi suatu hal yang terjadi dalam kehidupan atau lingkungan mereka. Dalam mencerna informasi dan isu yang beredar, diperlukan kematangan emosi yang baik, regulasi emosi yang tinggi, dan kontrol diri.

Kematangan emosi adalah suatu keadaan atau kondisi mencapai tingkat kedewasaan perkembangan emosional (Kartono, 2011). Berdasarkan pengertian tersebut, orang yang matang menunjukkan bahwa individu yang bersangkutan tidak lagi menampilkan emosi seperti yang dilakukan oleh anak-anak. Sedangkan menurut Hurlock (2001) kematangan emosi dapat diasumsikan sebagai keadaan atau reaksi perasaan yang stabil terhadap suatu objek permasalahan sehingga dalam melakukan tindakan dan mengambil keputusan didasari pada suatu pertimbangan. Hal ini akan membuat suasana hati cenderung stabil dan konsisten. Menurut Sumitro (2012), individu yang matang secara emosi memiliki beberapa kemampuan, di antaranya adalah mengungkapkan dan menerima emosi dengan baik, menunjukkan kesetiaan, menghargai orang lain serta realistis, menilai harapan dan inspirasi, menunjukkan rasa empati, meminimalisir pertimbangan yang bersifat emosional, toleransi, dan menghargai orang lain.

Dari beberapa penjelasan di atas, dapat disimpulkan bahwa kematangan emosi adalah kondisi ketika seseorang dapat mengontrol emosinya dalam berperilaku, mengambil keputusan, dan menanggapi sebuah masalah. Contohnya ketika menghadapi sebuah informasi yang ada atau keadaan yang terjadi, maka seseorang dengan kematangan yang baik dapat mempertimbangkan apa yang harus dilakukannya. Individu dengan kematangan emosi yang baik tidak mudah untuk mengumbar kebencian atau memprovokasi orang lain. 
Hal ini dikarenakan mereka akan bijak dalam menghadapi sebuah masalah.

Penelitian yang dilakukan oleh Gustiningsih \& Hartosujono (2017) dengan judul "Hubungan Kematangan Emosi dengan Kecenderungan Perilaku Cyberbullying pada Pengguna Twitter di Universitas Sarjanawiyata Tamansiswa Yogyakarta" mendapatkan hasil bahwa adanya hubungan negatif antara kematangan emosi dengan kecenderungan perilaku cyberbullying. Semakin tinggi kematangan emosi maka akan semakin rendah seseorang melakukan kecenderungan perilaku cyberbullying, dan sebaliknya.

Berdasarkan rangkaian penjelasan di atas, tujuan penelitian ini adalah untuk mengetahui hubungan antara kematangan emosi dengan perilaku ujaran kebencian yang terjadi karena kebijakan politik. Subarsono (2005) menjelaskan bahwa kebijakan politik merupakan sebuah keputusan yang dibuat dan ditetapkan atau tidak ditetapkan oleh badan-badan atau aparat pemerintah. Kebijakan politik yang dimaksud dalam penelitian ini adalah segala sesuatu yang berkaitan dengan kebijakan-kebijakan yang dibuat oleh pelaku politik seperti pemerintah daerah, menteri, maupun presiden. Misalnya pembuatan RUU atau kebijakan tentang pelepasan narapidana korupsi yang dikeluarkan oleh menteri hukum dan HAM.

Manfaat dari penelitian ini adalah untuk mengetahui seberapa berpengaruh kematangan emosi terhadap tindakan kebencian yang sedang marak terjadi. Penelitian ini juga dapat menjadi acuan kepada masyarakat untuk mengetahui bagaimana kematangan emosi dapat mempengaruhi tindakan ujaran kebencian, sehingga diharapkan masyarakat dapat menyadari bagaimana seharusnya bersikap dan mengambil keputusan tanpa harus mengujarkan kebencian pada media sosial. Maka bisa diambil hipotesis dalam penelitian ini yaitu terdapat hubungan negatif antara kematangan emosi dengan perilaku ujaran kebencian. Artinya, jika kematangan emosi tinggi maka tingkat perilaku ujaran kebencian pada seseorang akan rendah, begitupun sebaliknya.

\section{Metode}

\section{Subjek Penelitian}

Subjek penelitian ini berada pada rentang usia 20-40 tahun dengan total sejumlah 205 subjek. Subjek yang berusia 20 hingga 29 tahun sebanyak 180 orang $(87,8 \%)$ dan berusia 30 hingga 40 tahun sebanyak 25 orang (12.1\%). Subjek yang berjenis kelamin laki-laki sebanyak 93 orang $(45.4 \%)$ dan perempuan sebanyak 112 orang (54.6\%).

Pengambilan sampel menggunakan teknik purposive sampling. Teknik ini mengambil sampel dengan berbagai kriteria dan pertimbangan tertentu. Alasan peneliti menggunakan teknik ini adalah karena subjek yang akan digunakan dalam penelitian kali ini memiliki beberapa kriteria yang harus dipenuhi oleh subjek (Winarsunu, 2017). Adapun kriteria yang digunakan di antaranya adalah berusia 20 sampai 40 tahun, menggunakan media sosial, mengikuti berita dan isu politik, dan tidak sedang memiliki jabatan atau berada dalam pemerintahan.

\section{Variabel dan Instrumen Penelitian}

Terdapat dua variabel dalam penelitian ini, yaitu variabel bebas (x) dan variabel terikat (y). Variabel bebas (independent variabel) dalam penelitian kali ini adalah kematangan emosi, dan variabel terikatnya (dependent variabel) yaitu perilaku ujaran kebencian.

Definisi operasional dari kematangan emosi menurut Walgito (2004) adalah seseorang yang memiliki kematangan emosi yang baik dapat memenuhi aspek-aspek kematangan emosi. Aspek tersebut di antaranya memiliki penerimaan diri yang baik, tidak impulsive, memiliki kontrol emosi yang baik, berpikir objektif, dan bertanggungjawab. Tinggi rendahnya kematangan emosi pada subjek dapat dilihat dari skor total skala. Adapun kematangan emosi adalah kemampuan dalam mengendalikan emosi. Semakin tinggi skor yang diperoleh, maka akan semakin tinggi tingkat kematangan emosi dan berlaku sebaliknya.

Model yang digunakan dalam mengukur kematangan emosi seseorang adalah menggunakan skala likert. Skala likert ini telah digunakan oleh penelitian sebelumnya dengan judul "Hubungan Antara Kematangan Emosi dan Kecenderungan Perilaku Berselingkuh pada Individu Menikah" yang dilakukan oleh Erningtyas (2018). Dalam penelitian tersebut, skala kematangan emosi disusun berdasarkan aspek aspek menurut Walgito (2004). Isi aspek tersebut sama dalam penelitian ini, yaitu memiliki penerimaan diri yang baik, tidak impulsif, berpikir objektif, dan bertanggungjawab. Terdapat dua jenis pertanyaan pada skala ini, yaitu pertanyaan yang bersifat favorable dan pertanyaan yang bersifat unfavorable. Untuk menentukan skor total, terdapat perbedaan antara pertanyaan favorable dan unfavorable. Item favorable memiliki nilai 4 dalam pilihan Sangat Setuju (SS), nilai 3 dalam pilihan Setuju (S), nilai 2 pada pilihan Tidak Setuju (TS), dan nilai 1 dalam pilihan Sangat Tidak Setuju (STS). Sedangkan nilai dalam item unfavorable berlaku sebaliknya, yakni nilai 1 untuk jawaban Sangat Setuju (SS), nilai 2 untuk pilihan Setuju (S), dan nilai 3 untuk pilihan Tidak Setuju (TS), dan mendapat nilai 4 untuk pilihan Sangat Tidak Setuju (STS). Skala kematangan emosi ini memiliki 29 item dengan jumlah item favorable sebanyak 17 dan item unfavorable sebanyak 13 pertanyaan. Skor reliabilitas skala ini adalah 0,874 .

Meskipun diadaptasi dari penelitian terdahulu, peneliti tetap memodifikasi dan menganalisa ulang skala. Hal ini dikarenakan terdapat beberapa kriteria yang berbeda seperti lokasi dan subjek. Definisi operasional dari perilaku ujaran kebencian adalah sebuah tindakan verbal yang mengandung unsur kemarahan, kejijikan, dan perasaan devaluasi yang diekspresikan. Untuk mengukur kecenderungan perilaku ujaran kebencian terhadap isu politik, peneliti menggunakan skala vignette. Skala ini berisi deskripsi singkat tentang sebuah situasi dengan informasi yang dibutuhkan bagi responden atau subjek untuk menjadi dasar penilaian (Poulou, 2001). Alasan penggunaan skala vignette adalah karena dapat memberikan gambaran secara situasi kepada responden ketika mengisi agar mendapat hasil data semaksimal mungkin. Penyusunan skala vignette dilakukan berdasarkan tiga aspek kebencian menurut Sternberg \& Sternberg (2008). Ketiga aspek tersebut yaitu kejijikan, kemarahan, dan devaluasi. Perhitungan skor pada skala ini yaitu akan terdapat rentang jawaban yang berisi 7 poin, 
dengan susunan angka 1 pada sisi kiri dan 7 di sisi kanan. Angka tersebut menggambarkan nilai yang didapat oleh subjek. Pada skala, terdapat satu skenario dan tiga pertanyaan untuk mengukur perilaku ujaran kebencian.

Setelah melakukan uji validitas dan reliabilitas pada alat ukur, didapatkan hasil bahwa alat ukur ujaran kebencian dinyatakan valid seluruhnya dengan jumlah 6 item. Oleh karena itu, alat ukur ini mampu mengukur kecenderungan perilaku ujaran kebencian serta memiliki indeks validitas dalam rentang 0.496-0.829 dan dengan nilai reliabilitas 0.816. Pada alat ukur kematangan emosi, diperoleh 40 item dan terdapat 3 item tidak valid, sehingga jumlah item valid adalah 37 item. Hasil uji validitas tersebut mengindikasikan alat ukur ini dapat digunakan untuk mengukur kematangan emosi. Indeks validitas pada alat ukur kematangan emosi berada dalam rentang 0.205-0.560, dengan indeks reliabilitas 0.835 .

\section{Analisis Data}

Penelitian ini memiliki tiga prosedur utama. Tahap awal adalah persiapan. Tahap ini dimulai dari mencari fenomena yang marak terjadi di lapangan untuk dapat menentukan judul. Peneliti kemudian mengonsultasikan judul kepada dosen pembimbing. Setelah judul disetujui, dilanjutkan dengan memutuskan rumusan masalah dan landasan teori yang digunakan. Langkah selanjutnya adalah menentukan metode penelitian mulai dari subjek penelitian, teknik pengumpulan data, pengambilan sampel, dan instrumen penelitian. Setelah dosen pembimbing menyetujui metode penelitian dan instrumen yang digunakan, peneliti mengambil data secara langsung di lapangan.

Tahap kedua yaitu tahap pelaksanaan. Di tahap ini, peneliti menyebarkan instrumen penelitian yang telah ditetapkan. Penyebaran instrumen dilakukan dengan teknik purposive sampling, yakni teknik pengambilan sampel dengan berbagai kriteria dan pertimbangan tertentu. Sebelum disebar di lapangan, instrumen diujicobakan terlebih dahulu pada 50 responden. Penyebaran instrumen dilakukan melalui media sosial dengan platform Google Form yang telah dibuat.

Tahap terakhir dari penelitian ini adalah analisis hasil penelitian. Sebelum melakukan analisis, peneliti melakukan skoring atau penilaian pada setiap skala yang telah disebarkan. Skoring dilakukan berdasarkan blue print dari masing-masing skala. Selanjutnya adalah melakukan analisis statistik, dengan cara skor yang diperoleh dari hasil penilaian pada setiap skala diolah menggunakan program perhitungan statistik SPSS 21. SPSS 21 adalah aplikasi analisis parametrik dengan jenis dan interval. Untuk menguji hubungan antara dua variabel, maka dilakukan uji korelasi product moment pearson. Teknik tersebut digunakan untuk menguji rumusan masalah asosiatif (uji hubungan) dengan tujuan mengetahui hubungan antara dua variabel yang diteliti. Kemudian, peneliti membuat laporan hasil penelitian dengan menuliskan abstrak, hasil penelitian, diskusi dan kesimpulan (Winarsunu, 2017).

\section{Hasil}

Subjek dalam penelitian kali ini berada pada rentang usia 2040 tahun. Jumlah subjek yang berpartisipasi sebanyak 205 orang dengan jenis kelamin laki-laki dan perempuan dengan latar belakang pendidikan yang berbeda.

Berdasarkan hasil analisis, variabel perilaku ujaran kebencian memiliki nilai mean sebesar 20.26 dengaan standar deviasi sebesar 7.5. Nilai total dikategorikan menjadi 3 bagian yaitu rendah, sedang, dan tinggi. Untuk kategori rendah, memiliki interval $>13$, dengan frekuensi sebesar 41 dan persentase $20 \%$. Kemudian kategori sedang berada dalam interval $14-27$, dengan frekuensi sebesar 64 subjek dan persentase $64 \%$. Kategori tinggi berada dalam interval $<28$, dengan frekuensi sebesar 16 subjek dan persentase $16 \%$. Selanjutnya, variabel kematangan emosi memiliki mean 115.19 dengan standar deviasi 9,7. Variabel ini juga dibagi menjadi tiga kategori yaitu rendah, sedang, dan tinggi. Kategori rendah berada pada interval $>105$, dengan frekuensi sebanyak 34 subjek dan persentase sebesar $16 \%$. Kategori sedang berada dalam interval $106-124$ dengan frekuensi sebanyak 135 subjek dan persentase $66 \%$. Kategori tinggi berada pada interval $<125$ dengan jumlah frekuensi 36 subjek dan persentase sebesar 18\%. Dari hasil kategori variabel tersebut dapat disimpulkan bahwa tingkat perilaku ujaran kebencian tertinggi berada dalam kategori sedang dengan persentase sebesar 64\%, dan pada variabel kematangan emosi, nilai tertinggi berada pada kategori sedang dengan persentase $66 \%$.

Hasil uji beda menunjukkan nilai sig sebesar 0.005 $(\mathrm{p}<0.05)$ dalam variabel ujaran kebencian. Jika nilai sig $<0.05$ maka dapat disimpulkan bahwa terdapat perbedaan antara laki-laki dan perempuan dalam variabel tersebut. Nilai mean pada laki-laki adalah 21.87 (SD = 8.28) dan nilai mean pada perempuan sebesar 18.92 (SD = 6.62). Dapat diartikan bahwa laki-laki cenderung melakukan ujaran kebencian dibandingkan perempuan. Sedangkan pada variabel kematangan emosi, nilai sig yang diperoleh adalah 0.53 ( $\mathrm{p}>0.05$ ). Maka dapat diartikan bahwa tidak terdapat perbedaan yang signifikan terhadap variabel kematangan emosi yang dibedakan berdasarkan dengan jenis kelamin.

Berdasarkan kategori usia pada variabel ujaran kebencian, rentang usia 20-29 tahun memiliki nilai sig sebesar 0.073 (p $>0.05$ ). Artinya, tidak terdapat perbedaan yang signifikan pada variabel ujaran kebencian ditinjau dari kelompok usia. Pada variabel kematangan emosi, nilai sig yang didapat adalah 0.69 ( $\mathrm{p}>0.05)$. Hal ini menunjukkan bahwa tidak terdapat perbedaan yang signifikan antara kedua kelompok usia dalam variabel kematangan emosi.

Sebelum melakukan uji korelasi, peneliti melakukan uji kenormalan data. Uji kenormalan data dilakukan dengan one-sample kolmogorov-smirnov test, kedua variabel memiliki nilai signifikansi sebesar 0.200 ( $\mathrm{p}>0.05)$, sehingga data hasil penelitian berdistribusi normal.

Adapun hasil uji korelasi menunjukkan nilai $r$ sebesar -0.313 . Koefisien korelasi yang bertanda negatif menunjukkan bahwa hubungan yang terjadi antara kedua variabel berbanding terbalik atau tidak satu arah. Artinya, semakin tinggi tingkat kematangan emosi seseorang maka tingkat perilaku ujaran kebencian akan semakin rendah, dan begitupun sebaliknya. 


\section{Diskusi}

Penelitian kali ini dilakukan dengan tujuan untuk mengetahui hubungan antara kematangan emosi dengan perilaku ujaran kebencian di media sosial terhadap isu politik. Data menunjukkan adanya hubungan negatif antara ujaran kebencian dan kematangan emosi dengan nilai $r=-0.313$ dan $p$ $=0.000(p<0.05)$. Hal ini menunjukkan bahwa semakin tinggi tingkat kematangan emosi, maka akan semakin rendah kecenderungan seseorang untuk melakukan ujaran kebencian di media sosial dan sebaliknya. Hasil ini sejalan dengan penelitian yang dilakukan oleh Febriani (2018), yang mengatakan bahwa salah satu faktor yang memengaruhi terjadinya kebencian adalah kematangan emosi. Kematangan emosi sendiri menjadi dasar dalam perkembangan individu dan dapat memengaruhi bagaimana seseorang tersebut berperilaku (Gunarsa, 2008). Seseorang dengan tingkat kematangan emosi yang baik cenderung tidak melakukan ujaran kebencian pada media sosial meski saat melihat stimulus yang menurutnya negatif. Oleh karena itu, hipotesis penelitian ini dapat diterima.

Kematangan emosi berperan dalam menentukan output perilaku apa yang akan ditunjukkan seseorang kepada lingkungan sekitarnya. Ini sejalan dengan penelitian Walgito (2004) yang mengatakan bahwa kematangan emosi adalah kemampuan seseorang dalam mengendalikan sebuah emosi dan dapat berpikir secara matang, baik, dan objektif. Salah satu aspek kematangan emosi adalah dapat mengontrol emosi, sedangkan kebencian adalah sebuah emosi negatif. Seseorang dengan kematangan emosi yang baik tidak akan berperilaku impulsive dan dapat mengontrol respon yang akan dikeluarkan ketika mendapat stimulus negatif. Dengan demikian, ia akan cenderung memilih tidak akan melakukan ujaran kebencian di media sosial, begitu pula sebaliknya.

Hasil penelitian menunjukkan bahwa variabel ujaran kebencian memiliki kategori sedang dengan persentase sebesar $64 \%$. Kemudian pada variabel kematangan emosi memiliki persentase $66 \%$. Dari hasil tersebut menunjukkan bahwa antara kedua variabel memiliki frekuensi terbayak pada kategori sedang. Banyak penelitian lain yang mengatakan bahwa penyebab kebencian diantaranya adalah faktor psikologis dan keadaan emosi seseorang. ketika seseorang dengan kematangan emosi yang baik ia akan memiliki kemampuan dalam mengendalikan emosi dan dan dapat berpikir secara matang ketika ia merasakan sebuah perasaan marah, sehingga ketika ia akan mengungkapkan kemarahannya ia akan cenderung untuk tidak melakukan perilaku yang bersifat negatif. Walgito (2004), menjelaskan bahwa kematangan emosi adalah kemampuan individu dalam mengendalikan emosi dan dapat berpikir secara matag, baik, dan objektif. Selain hal salah satu aspek dalam kematangan emosi adalah tidak impulsif (Walgito, 2004), yaitu seseorang akan mampu mengontrol respon dari sebuah stimulus yang datang padanya, sehingga ketika mendapat sebuah stimulus yang negatif maka ketika akan memberikan respon kepada sebuah stimulus seseorang tersebut akan mampu memberikan respon yang baik dan tidak merugikan orang lain.

Kematangan emosi dan perilaku ujaran kebencian memang berkaitan. Seseorang yang melontarkan ujaran kebencian di media sosial bisa jadi kurang mampu mengontrol respon dari perilaku yang diberikan, sehingga cenderung tidak memikirkan dampak dari apa yang telah ia lakukan. Goleman (2000) mengatakan bahwa munculnya perilaku negatif terhadap sebuah stimulus yang datang merupakan sebuah gambaran dari peningkatan emosi yang tidak seimbang dalam diri seseorang.

Hasil menunjukkan adanya perbedaan antara lakilaki dan perempuan pada variabel ujaran kebencian. Laki-laki mendapat nilai mean sebesar 21.87, lebih tinggi dari perempuan yang hanya sejumlah 18.92. Hal tersebut menjelaskan bahwa laki-laki cenderung lebih sering melakukan ujaran kebencian daripada perempuan. Namun pada kematangan emosi, tidak terdapat perbedaan yang signifikan antara laki-laki dan perempuan. Meski begitu, jika dilihat dari nilai mean yang didapat, kematangan emosi perempuan lebih baik dari pada laki-laki. Hal ini disebabkan jenis kelamin merupakan sosialisasi awal emosi terhadap seseorang. Laki-laki diharapkan lebih mandiri, percaya diri, dan ekspresif, sedangkan perempuan diharapkan lebih hangat secara emosional dan suka menolong (Davis dalam Astuti \& Ekowarni (2005)). Laki-laki cenderung melakukan ujaran kebencian lebih karena mereka lebih ekspresif sedangkan perempuan lebih memiliki kehangatan secara emosional.

Kematangan emosi merupakan kemampuan seseorang dalam mengendalikan emosi secara baik. Seseorang dengan kematangan emosi yang baik dapat mempertimbangkan sebuah keputusan dengan baik walaupun sedang dalam keadaan yang kurang baik dan mendapat stimulus yang tidak baik menurutnya (Piaget dalam Daryanto, 2007). Penelitian kali ini melihat bagaimana kematangan emosi memengaruhi seseorang dalam melakukan ujaran kebencian di media sosial terhadap isu politik. Dari hasil uji korelasi pearson, nilai koefisien korelasi yang didapat adalah -0,313, yang menunjukkan adanya hubungan negatif antara kematangan emosi dengan ujaran kebencian. Sedangkan nilai signifikasi sebesar 0,000 dan kurang dari 0,05. Nilai ini menunjukkan adanya hubungan antara variabel yang diteliti. Penelitian yang dilakukan oleh Widasuari \& Laksmiwati (2018) juga menunjukkan bahwa seseorang dengan kematangan emsoi yang baik cenderung memaafkan sebuah stimulus yang datang, sedangkan seseorang dengan kematangan emosi rendah memberikan respon yang bersifat negatif.

Menurut penelitian terdahulu, ada beberapa aspek lain yang mendorong seseorang melakukan ujaran kebencian. Di antaranya adalah keadaan psikologis, kematangan emosional, faktor lingkungan, kurangnya kontrol sosial, kepentingan kelompok atau masyarakat, dan ketidaktahuan masyarakat (Febriani, 2018). Terlebih di Indonesia, isu politik merupakan salah satu dari banyak hal yang sensitif.

Emosi yang ditimbulkan oleh sebuah stimulus yang datang pada dasarnya dapat ditahan dan dikontrol agar tidak memberikan sebuah output perilaku yang bersifat negatif. Seseorang memiliki tingkat kematangan emosi yang baik karena memiliki salah satu aspek kematangan emosi yaitu rasa tanggung jawab. Seseorang yang bertanggungjawab cenderung memikirkan sebuah keputusan untuk melakukan seseatu. Dengan hal tersebut, seseorang dengan kematangan emosi yang baik cenderung akan tidak melakukan ujaran kebencian di media sosial atau mengekspresikan kebencian dengan cara yang lebih positif. 
Kelemahan dari penelitian kali ini adalah belum banyak kajian secara spesifik mengenai ujaran kebencian dari sudut pandang psikologi. Hal ini menyebabkan beberapa referensi dan teori yang diambil kebanyakan bukan dari psikologi. Alat ukur penelitian kali ini juga jarang ditemui. Kelemahan lainnya yaitu pemilihan subjek kurang spesifiknya, seperti pengelompokkan kriteria dan data demografis subjek. Kemudian, skala vignette dalam penelitian ini belum melalui tinjauan ahli terlebih tentang berita yang digunakan, apakah sudah memenuhi syarat berita kebijakan politik. Adapun kelebihan dari penelitian kali ini adalah topik yang menarik untuk dibahas karena Indonesia sedang mengalami tahun politik belakangan ini dan tak sedikit pula gejolak yang terjadi. Skala vignette juga jarang digunakan dalam penelitian, sehingga dapat menjadi referensi baru ketika peneliti selanjutnya ingin menggunakan alat ukur ini.

\section{Kesimpulan}

Hasil dari penelitian kali ini adalah diterimanya hipotesis, yang menunjukkan bahwa adanya hubungan negatif antara kematangan emosi dengan perilaku ujaran kebencian. Seseorang dengan tingkat kematangan emosi yang baik memiliki kecenderungan rendah melakukan ujaran kebencian di media. Begitupun sebaliknya, ketika seseorang memiliki kematangan emosi yang rendah, maka ia memiliki kecenderungan tinggi melakukan ujaran kebencian di media sosial.

Implikasi yang didapat dari penelitian ini yaitu penting untuk diketahui bahaya ujaran kebencian dalam media sosial. Diharapkan setiap lapisan masyarakat juga dapat mereduksi ujaran kebencian. Hal-hal yang dapat dilakukan untuk menguranginya adalah meningkatkan kematangan emosi setiap individu. Kematangan emosi dapat membaik dengan berbagai cara, seperti bersosialisasi dengan orang lain, melihat masalah yang datang dari berbagai sudut pandang, meningkatkan keterbukaann dalam hubungan sosial, dan lain-lain. Untuk meningkatkan kematangan emosi dan menghindari perilaku ujaran kebencian di media sosial, beberapa hal yang dapat dilakukan di antaranya adalah tidak melihat berita atau sebuah informasi hanya dari satu sumber saja. Selain itu, jangan menyebarkan berita yang belum pasti kebenarannya agar tidak memprovokasi orang awam menyebabkan hoaks. Masukan untuk peneliti selanjutnya yaitu dapat meneliti variabel ujaran kebencian ini dengan menggunakan metode kualitatif.

\section{Referensi}

Al Ayyubi, S. (2018, Juni 26). Kasus Ujaran Kebencian Periode Januari-Juni 2019 Merangkak Naik. Diakses dari: https://kabar24.bisnis.com/read/20190626/16/937961/kasusujaran-kebencian-periode-januari-juni-2019-merangkak-naik.

Astuti, B., \& Ekowarni, E. (2005). Kematangan emosi anak kelas 6 sekolah dasar ditinjau dari persepsi anak terhadap kedemokratisan pola asuh ayah dan ibu. Tesis. Fakultas Psikologi, Universitas Gadjah Mada, Yogyakarta.

Azra, A. (2018, 15 Oktober). Kejahatan kebencian. Diakses dari https://kompas.id/baca/utama/2019/08/29/pidana-kebencian/.

Bavel, J. J. V., Ray, J. L., Granot, Y., Cunningham, W. A. (2014). The psychology of hate: Moral concerns differentiate hate from dislike. ol PsyArXiv Preprint, 1-51. doi 10.31234/osf.io/x9y2p
Daryanto. (2007). Evaluasi pendidikan. Jakarta. Rineka Cipta.

detik.com (25 Oktober 2019)

Eriningtyas, R. (2018). Hubungan antara kematngan emosi dan kecenderungan perilaku berselingkuh pada individu menikah. Skripsi. Fakultas Psikologi, Universitas Sanata Dharma, Yogyakarta.

Febriani, M. (2018). Analisis faktor penyebab pelaku melakukan ujaran kebencian (hate speech) dalam media social. Skripsi. Fakultas Hukum, Universitas Lampung, Bandar Lampung.

Fisher, A., Halperin, E., Canetti, D., \& Jasini, A. (2018). Why we hate. Emotion Review, 10(4), 309-320. https://doi.org/10.1177/1754073917751229

Goleman, D. (2000). Emotional Inteligence (terjemahan). Jakarta: PT. Gramedia Pustaka Utama.

Gunarsa, S. D. (2008). Psikologi perkembangan anak dan remaja. Jakarta: BPK Gunung Mulia.

Gustiningsih, S., \& Hartosujono, H. (2017). Hubungan kematangan emosi dengan kecenderungan perilaku cyberbullying pada pengguna twitter di universitas sarjanawiyata tamansiswa yogyakarta. Jurnal Spirits, 4(1), 64. https://doi.org/10.30738/spirits.v4i1.1033

Halperin. E. (2008). Group-based hatred in intractable conflict in israel. Journal of Conflict Resolution, 52(5), 713-736.

Hurlock, E. B. (2001). Psikologi perkembangan: Suatu pendekatan sepanjang rentang kehidupan. Jakarta: Erlangga.

Judhita, C. (2017). Hate speech di media online: Kasus pilkada dki jakarta 2017. Jurnal Penelitian Komunikasi dan Opini Publik, 137-151. doi: http://dx.doi.org/10.33299/jpkop.21.2.1134

Kartono, K. (2011). Pemimpin dan kepemimpinan. Jakarta: PT. Rajawali Grafindo Persada.

Komisi Nasional Hak Asasi Manusia Republik Indonesia. (2016). In Buku Saku Penanganan Ujaran Kebencian (Hate Speech) (p. 3).

Kompas.com (2 Februari 2019)

Poulou, M. 2001. The role of vignettes in the research of emotional and behavioural difficulties. Journal Emotional and Behavioural Difficulties. 6(1): 50-62.

Purnamasari, N. (2018, Oktober 25). Wiranto: Ada 53 kasus hoax dan 324 hate speech sepanjang 2018. Diakses dari: https://news.detik.com/berita/d-4272642/wiranto-ada-53kasus-hoax-dan-324-hate-speech-sepanjang-2018

Sinaga, L. V. (2019). Tinjauan sosial dalam pencegahan ujaran kebencian dalam media sosial pada pemilihan presiden tahun 2019. Jurnal Rectum, 1(1), 10-17.

Sternberg, R. J., \& Sternberg, K. (2008). Cognitive psychology (6th ed.). Canada: Cengage Learning.

Subarsono, A.B. (2005). Analisis kebijakan publik: Konsep, teori, dan aplikasi. Yogyakarta: Pustaka Pelajar.

Sukmana, Y. (2018, Februari 22). Maraknya Ujaran Kebencian Berkaitan Erat dengan Politik. Diakses dari https://nasional.kompas.com/read/2018/02/22/17183311/maraknyaujaran-kebencian-berkaitan-erat-dengan-politik.

Sumitro, A. (2012). Hubungan antara kematangan emosi dengan problem focused coping mahasiswa di ma'had putra sunan ampel al ali uin maliki malang. (Skripsi). Fakultas Psikologi Universitas Islam Negeri Maulana Malik Ibrahim, Malang.

Trajkova, Z. \& Neshkovska, S. (2018). Online hate propaganda during election period: The case of macedonia. Lodz Papers in Pragmatics, 14, 309-334. 
Walgito, B. (2004). Pengantar psikologi umum. Yogyakarta: Andi. Wearesosial. (2019, Januari). Berapa pengguna media sosial indonesia. Diakses dari https://databoks.katadata.co.id/datapublish/2019/02/08/berapapengguna-media-sosial-indonesia.

White, R. S. (1996). Psychoanalytic process and interactive phenomena. Journal of the American Psychoanalytic Association, 44(3), 699-722.
Widasuari, D., \& Laksmiwati, H. (2018). Hubungan antara kematangan emosi dengan forgiveness pada mahasiswa psikologi. Jurnal Penelitian Psikologi Universitas Negeri Surabaya, 5(2), 1-6.

Winarsunu, T. (2017). Statistik dalam penelitian psikologi dan pendidikan. Malang: UMM Press. 